
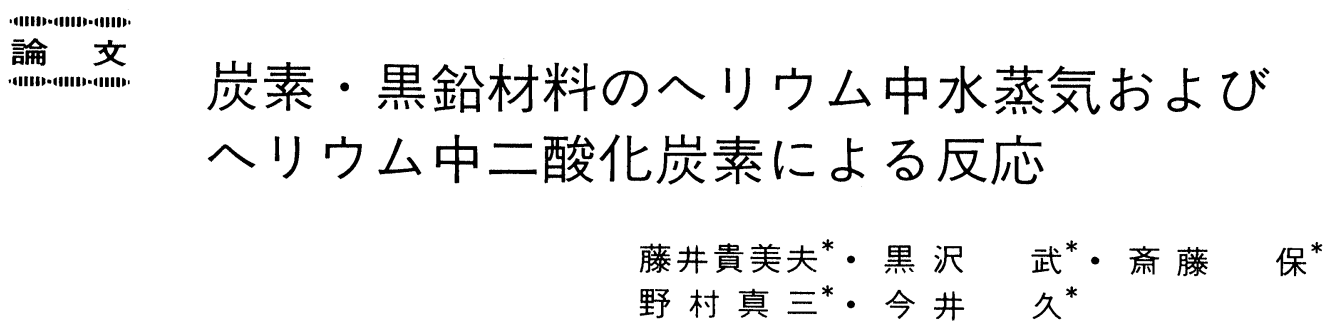

（昭和 58 年 6 月 29 日受理）

\title{
Reactions of Carbons and Graphites with Water Vapor or Carbon Dioxide in Helium
}

\author{
Kimio Fujii, Takeshi Kurosawa, Tamotsu Saito, \\ Sinzo Nomura and Hisashi Imai \\ Japan Atomic Energy Research Institute, \\ Tokai-mura, Ibaraki-ken 319-11, Japan
}

\begin{abstract}
Seventeen kinds of carbons and graphites were oxidized in helium flow containing $0.65 \%$ of water vapor or carbon dioxide in the temperature range from 800 to $1000^{\circ} \mathrm{C}$. The rate of reaction with carbon dioxide was relatively equal to that with water vapor. Correlations between the rates and some characters such as the concentrations of impurity contained in the materials and their $X$ ray parameters of structure were also investigated. Only the concentrations of iron impurity were related to the rates, and the total of the concentrations of iron and those of titanium, vanadium and nickel were more closely related to the rates. The compensation effects, which are characteristic to catalytic reaction, were found to exist between the activation energies for the reactions and the pre-exponential factors. Iso kinetic temperatures, at which all catalysts lose their effect, were $1550^{\circ} \mathrm{K}$ for the reaction with water vapor and $1380^{\circ} \mathrm{K}$ for the reaction with carbon dioxide.
\end{abstract}

\section{1. 緒言}

日本原子力研究所で開発を進めている多目的高温ガス 実験炬には，炉内の構造物として 300 トン以上の黑鉛材 料と 10 トン未満の炭素質材料を使用する。冷却材として は高純度のヘリウムを使用するが，ての中に微量の不純物 ガスが混入してくることは避けられない。この結果原子炉 内部では正常な運転時に扔いてもへリウム中不純物ガス 之高温になっている黑鉛構造物との間で反応が起り, 炭 素のガス化による材質の劣化が進行していく。したがっ ててこで使用する材料には，腐食性不純物ガスに対して 反応しにくい黒鉛材料や炭素質材料を使用することが要 求される。そして次のステップとして実用材料の使用限 界を明らかにするために，不純物ガスによる腐食速度， 腐食の進行様態, 腐食による特性変化等を把握しておく

\footnotetext{
*日本原子力研究所燃料工学部： $\bar{\top} 319-11$ 茨城県那珂 郡東海村
}

\section{ことが必要である。}

高温ガス炉のヘリウム冷却材中には 6 種類程の不純物 ガスが存在するとされているが ${ }^{1)}$ ，乙れらのなかで炭素 に対する反応性とその存在濃度からみて, 主要な腐食性 不純物ガスは水蒸気と二酸化炭素である。この報告は 17 銘柄にのぼる炭素・黒鉛材料のヘリウム中水蒸気及びへ リウム中二酸化炭素による反応の研究結果である。へリ ウム中 $0.65 \%$ 濃度のガスによる $800 \sim 1000^{\circ} \mathrm{C}$ の応速度 を測定し，雨ガスによる反応速度の相対的大きさを求め て, 高温ガス炉の黒鉛構造物の腐食に及ぼす両ガスの影 響度合について検討した。またガスに対する炭素・黒鉛 材料の反応性を支配する因子を明らかにするため，材料 の含有不純物や結晶構造パラメータ一等各種特性と反応 速度, 反応の活性化エネルギーとの関係を調べたほか, 雨反応で観察されたCompensation effectについて検討 を加えた。 


\section{2. 実}

\section{験}

\section{1 炭素・黒鉛材料}

実験に使用した 17 種類の炭素及び黒鉛材料をTable 1 亿示す。17 銘柄は輸入品之国産品からなり，石油コ 一クス系が 7 銘柄, ピッチコークス系が 7 銘柄, 残る 3 銘柄のコークスは明らかにされていない。試験片はすべ て各銘柄の単一の素材から切出した。試験片の採取は素 材の直径が $1,000 \mathrm{~mm}$ 以上のあのでは材質の均一性も調 べるために，中心や外縁部分等複数の場所からあ行った。 したがって, 当研究のなかの個々の実験では一銘柄から 一つ以上のデータを得ている場合もある。試験片の寸法 は直径 $11 \mathrm{~mm}$, 長さ $50 \mathrm{~mm}$ の円柱型でその長さ方向を with grainに統一した。各材料についてはX線回折法に よって黒鉛化度, 結晶子径, 格子ひずみを測定した。黒 鉛化度は $\mathrm{Cu} の \mathrm{~K}_{\alpha}$ 線で得た 004 回折線から求めた格子定 数を用いて Méring 等の方法で計算し ${ }^{2)}$, 結晶子径と格 子ひずみは 002,004,006 回折線から Thrower 等の方 法で求めたものである ${ }^{3)}$ 。また一部の材料を除いて，含 有灰分濃度の測定と不純物の分析が当研究所の分析セン ターで行なわれた。灰分濃度は粉末約 $3 \mathrm{~g}$ を空気中 900 ${ }^{\circ} \mathrm{C}$ で酸化し, 残椬をひょう量して得た。一方不純物の分 析は $\mathrm{Fe}, \mathrm{Ca}, \mathrm{Mg}, \mathrm{Ni}, \mathrm{Mn}, \mathrm{Ti}, \mathrm{V}, \mathrm{Al}$ 等について行な われた。分析法は Feがオルトフェナントロリン光度法,

Table 1 Carbons and graphites used in the experiments

\begin{tabular}{|c|c|c|c|}
\hline Brand & Coke & $\begin{array}{c}\text { Compaction } \\
\text { method }\end{array}$ & $\begin{array}{c}\text { Apparent Density } \\
\left(\mathrm{g} / \mathrm{cm}^{3}\right)\end{array}$ \\
\hline ATR-2E & Special & $\mathrm{E}^{* *}$ & 1.81 \\
$\mathrm{P}_{3}$ JHA & Pitch coke & $\mathrm{M}^{* * *}$ & 1.73 \\
TS-1240 & - & $\mathrm{E}$ & 1.76 \\
$\mathrm{H} 451$ & Petroleum coke & $\mathrm{E}$ & 1.74 \\
$\mathrm{~V}-483 \mathrm{~T}$ & Pitch coke & Isostatic M & 1.77 \\
$\mathrm{ATJ}$ & - & $\mathrm{M}$ & 1.78 \\
$\mathrm{ASR}-1 \mathrm{RG}$ & Pitch coke & Vibrational M & 1.80 \\
$\mathrm{PGX}$ & - & $\mathrm{M}$ & 1.74 \\
$7477 \mathrm{PT}$ & Petroleum coke & $\mathrm{M}$ & 1.74 \\
7477 & " & M & 1.75 \\
$\mathrm{H} 327$ & " & $\mathrm{E}$ & 1.77 \\
$\mathrm{IG}-11(\mathrm{R})$ & " & Isostatic press & 1.75 \\
$\mathrm{IG}-11(\mathrm{~S})$ & " & " & 1.75 \\
$\mathrm{C}-140 \mathrm{~A}^{*}$ & Pitch coke & Vibrational M & 1.66 \\
$\mathrm{G}-117$ & " & $\mathrm{M}$ & 1.55 \\
$\mathrm{EG}-38 \mathrm{~B}^{*}$ & Petroleum coke & $\mathrm{M}$ & 1.57 \\
$\mathrm{CP} 101^{*}$ & Pitch coke & Isostatic press & 1.54 \\
\hline
\end{tabular}

(R): Round type block, (S): Square type block

* Carbon, ** Extrusion, *** Molding
$\mathrm{Ca}, \mathrm{Mg}, \mathrm{Ni}, \mathrm{Mn}$ が原子吸光法, Ti がジアンチピリル メタン光度法, $\mathrm{V}$ が $\mathrm{N}$ 一ベンゾイルフェニルヒドロキシ ルアミン抽出光度法, $\mathrm{Al}$ がオキシン抽出光度法である。 材料の灰分濃度は 80 2400 ppm飞分布しており，大型 素材では例外なく中心部分の方が外縁部分より 40〜80 \%だけ多かった。不純物では一般的な傾向として高純度 材料の場合, $\mathrm{Ti}$ の含有量が最も多く, 次いで $\mathrm{Fe}, \mathrm{Ca}$, Vがそれぞれ $20 \mathrm{ppm}$ 前後含まれていたが, $\mathrm{Al}$ は存在し なかった。一方比較的純度の低い材料では, Ti, Vの含 有量は高純度のものとほとんど変らないが, Fe と Ca が 〜 $10^{2}$ 倍増加し, $\mathrm{Ni}$ が $10 \mathrm{ppm}$ 前後, $\mathrm{Al}$ が多いあので $100 \mathrm{ppm}$ 程度含まれていた ${ }^{4)}$ 。

採取加工した試験片は特級の四塩化炭素中で超音波洗 浄した後, 空気中 $120^{\circ} \mathrm{C}$ で 48 時間以上乾燥させてからガ ラス製の乾燥容器中に保存した。

\section{2 反応ガス}

$0.65 \%$ の水蒸気を含むへリウムは, 市販の 6 ナイン級 高純度へリウムを， $2^{\circ} \mathrm{C}$ 亿保持した蒸留水中をくぐらせ て得た。他方二酸化炭素を含むへリウムは, 同じく市販 の JIS-K2 規格の二酸化炭素を, 常温のモレキラシー ブ $5 \mathrm{~A}$ カムを通して精製してからへリウムで希釈して

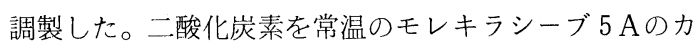
ラムに通すと, 吸着のため一時流れは停止するがやがて 流出し始め, 不純物として含まれていたメタンとエチレ ンが除去された。

（1）ヘリウム中水蒸気による反応

実験に使用した反応装置の系統図を Fig.1亿示す。装置はへリウム供給ボン ベ, ガス流量調節計, 水蒸気添加部, 反 応用電気炉，ガス分析装置及びガス放出 部から構成され，各部はパイレックスガ ラス管と銅管によって連結されている。 反応は試験片をまず真空中 $1000^{\circ} \mathrm{C}$ で 15 時間加熱して吸着ガスを除去してから， $0.65 \%$ の水蒸気を含むへリウムを電気炉 に導入して開始した。反応管を経由して きたガスは一部を分析のためガスクロマ トグラフに導入したほかは大気中に放出 した。ガス圧力は一気圧, ガス流量は $650 \mathrm{ml} / \mathrm{min}$ で試験片表面での線流速は $31 \mathrm{~mm} / \mathrm{sec}$ であった。実験中の反応用 電気炉の温度変動は士 $2^{\circ} \mathrm{C}$ 以下である。 反応速度 $R_{\mathrm{H}_{2} \mathrm{O}}$ （単位 $\mathrm{mg} / \mathrm{cm}^{2} \cdot \mathrm{hr}$ ）は, 生 成した $\mathrm{CO}$ 及び $\mathrm{CO}_{2}$ の合計濃度とガス流 量から次式に従って計算した。こてで単 位中の $\mathrm{mg}$ は試験片の減少重量, $\mathrm{cm}^{2}$ は 


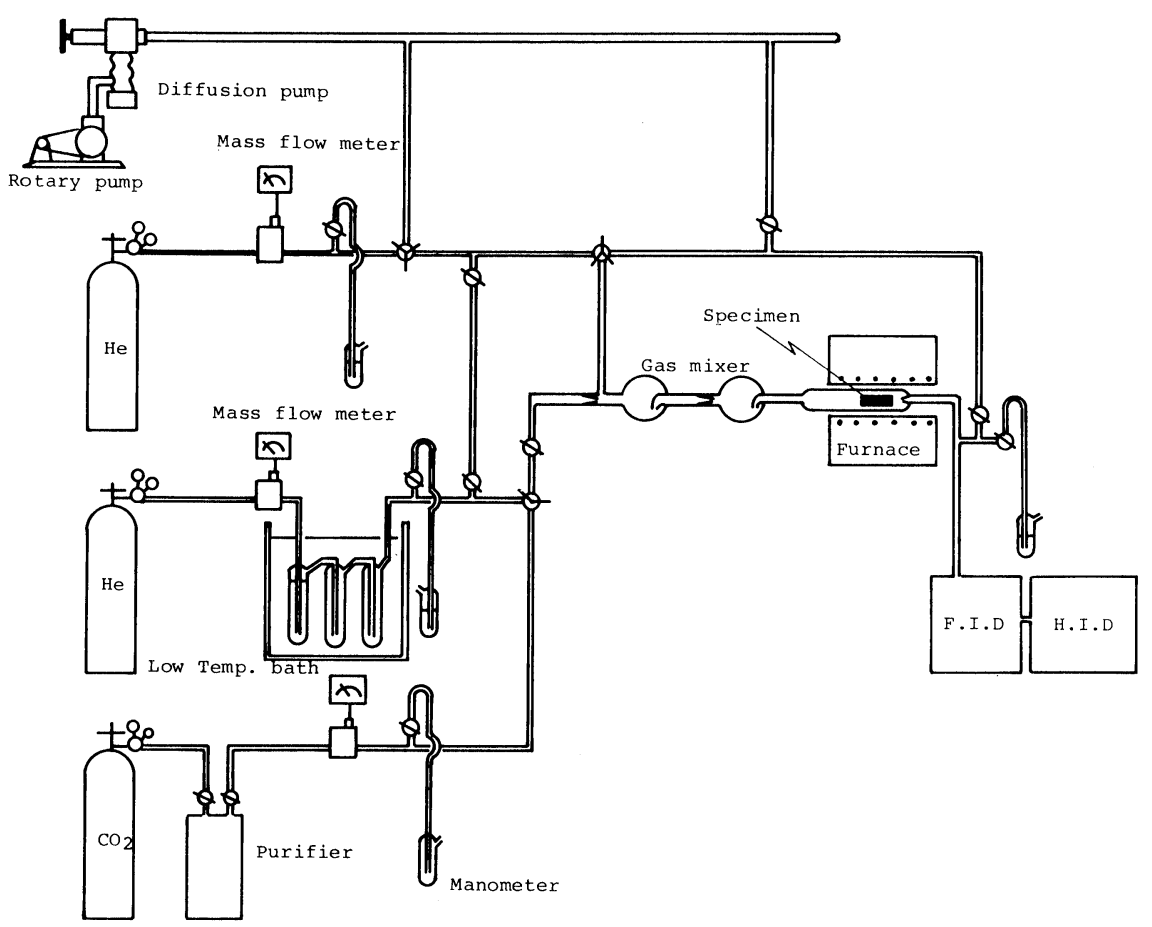

Fig. 1 Apparatus for the reaction

試験片の外部表面積，hr は時間である。

$$
\begin{aligned}
R_{\mathrm{H}_{2} \mathrm{O}}= & \frac{650 \times 60 \times\left(\mathrm{CO}+\mathrm{CO}_{2} \text { のヘリウム中 } \mathrm{vpm}^{* 1}\right)}{22,400 \times 10^{6} \times \text { 試験片の外部表面積 }} \\
& \times 12,000
\end{aligned}
$$

（2）ヘリウム中二酸化炭素による反応

水蒸気反応の場合と同じ装置を使用した。二酸化炭素 を流量調節計で毎分 $4.2 \mathrm{ml}$ に調節し， $646 \mathrm{ml}$ のヘリウ ムで希釈混合して反応電気炉入導入した。反応速度 $R_{\mathrm{CO}_{2}}$ (単位 $\mathrm{mg} / \mathrm{cm}^{2} \cdot \mathrm{hr}$ ) は, 反応生成物の $\mathrm{CO}$ 分析值加ら水蒸 気の場合と同様にして求めた。

$$
\begin{aligned}
R_{\mathrm{CO}_{2}}= & \frac{650 \times 60 \times(\mathrm{CO} \text { のリウムム } \mathrm{vpm} / 2)}{22,400 \times 10^{6} \times \text { 試験片の外部表面積 }} \\
& \times 12,000
\end{aligned}
$$

なお，反応温度はいずれの反応も $800 \sim 1000^{\circ} \mathrm{C}$ である。

\section{3. 結果}

\section{1 水蒸気による反応速度と二酸化炭素による 反応速度の相関性}

ヘリウム中 $0.65 \%$ の水蒸気及び二酸化炭素による雨反 応の反応速度を対比させた図が Fig. 2 と 3 である。Fig. 2 が $860^{\circ} \mathrm{C}, 3$ が $1000^{\circ} \mathrm{C}$ 反応速度である。 $1000^{\circ} \mathrm{C}$ の 場合, 反応速度は雨反応と屯反応を開始してから 5 時間 位までは変化するので，開始 10 時間後の值を使用した。
なお $1000^{\circ} \mathrm{C}$ 反応後の試験片のうち, 7477 黑鉛について 内部の密度分布を切削法で測定してみたところ，表面か ら $0.5 \mathrm{~mm}$ 以下の深さでは均一であった。したがって 1000 ${ }^{\circ} \mathrm{C}$ の場合む反応はほぼ化学反応律速で進行したとみて差 しつかえない。雨図ともプロットは多少のバラッキはあ るものの傾向としては右上がりの関係にあり, 雨反応速 度の間に一定の関連性のあることが伺える。雨反応速度 の関係を最小自乗法を使用して直線で表わすと, $860^{\circ} \mathrm{C}$ では

$$
R_{\mathrm{CO}_{2}}=0.9 \times R_{\mathrm{H}_{2} \mathrm{O}}
$$

となり, 二酸化炭素による反応速度の方が $10 \%$ 小さいと いう傾向があった。一方 $1000^{\circ} \mathrm{C}$ では

$$
R_{\mathrm{CO}_{2}}=1.1 \times R_{\mathrm{H}_{2} \mathrm{O}}
$$

と表わされ, $860^{\circ} \mathrm{C}$ 場合とは逆に二酸化炭素の方が 10 \%大きいという関係が得られた。なお(3) 式と (4) 式で 表わされる雨反応速度の相関性は (3) 式の相関係数が 0.84，(4) 式が 0.85 であった。

\section{2 反応速度と含有不純物及び反応の活性化エ} ネルギーと含有不純物との関連性

Fig. 4 に $1000^{\circ} \mathrm{C}$ に打ける反応速度と灰分濃度, 同じく $\mathrm{Ca}, \mathrm{Ti}, \mathrm{V}, \mathrm{Ni}, \mathrm{Fe}$ 濃度との関係をそれぞれ示した。な お $\mathrm{Mg}, \mathrm{Mn}$ についてはこれらの含有濃度が他の元素の

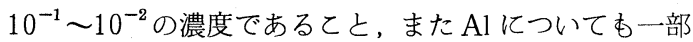
の材料にしか含有されていないととからとの 3 種の不純 


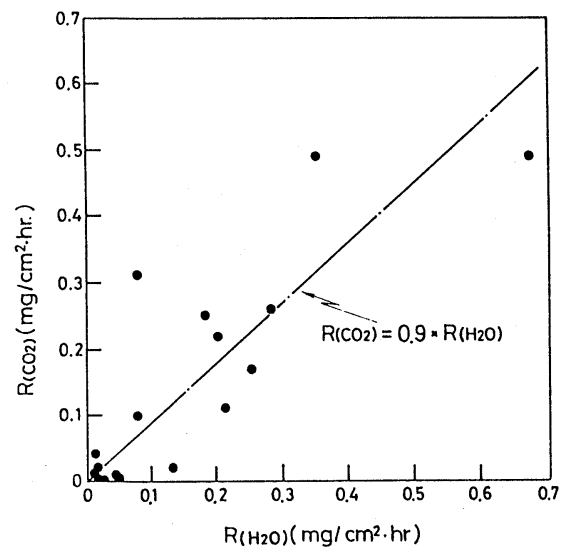

Fig. 2 Relation between the reaction rate with water vapor and that with carbon dioxide at a gas concentration of $0.65 \%$ in helium at $860^{\circ} \mathrm{C}$

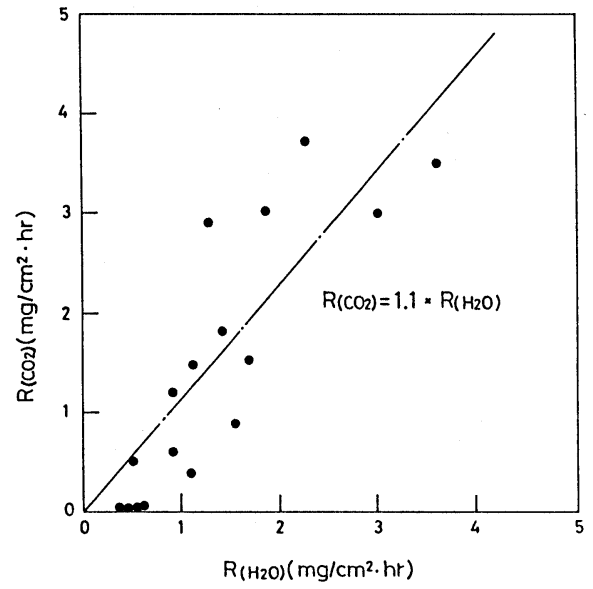

Fig. 3 Relation between the reaction rate with water vapor and that with carbon dioxide at a gas concentration of $0.65 \%$ in helium at $1000^{\circ} \mathrm{C}$
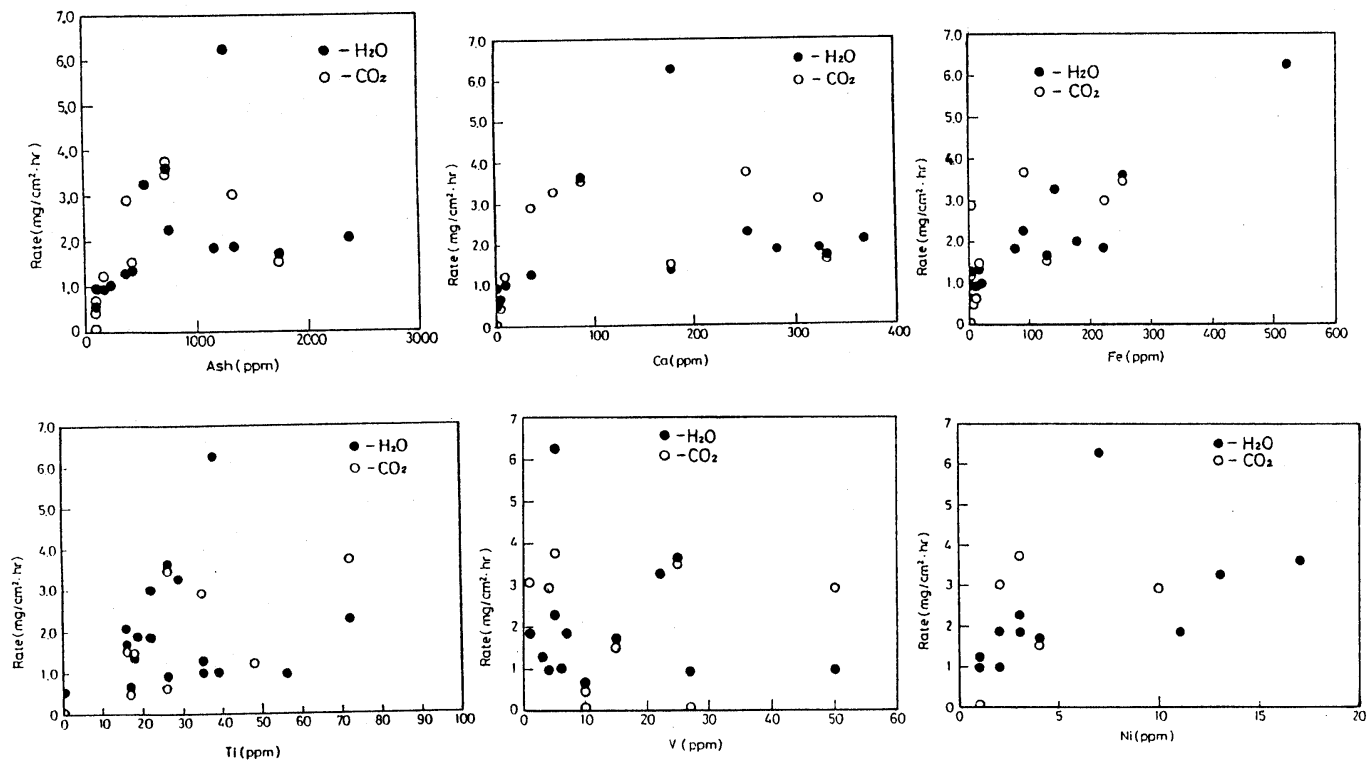

Fig. 4 Relations between the reaction rates with gases of $0.65 \%$ in helium at $1000^{\circ} \mathrm{C}$ and the concentrations of ash, $\mathrm{Ca}, \mathrm{Ti}, \mathrm{V}, \mathrm{Ni}$ and $\mathrm{Fe}$ contained in the specimens

物元素については検討しなかった。とてで灰分の場合， その濃度は含有不純物元素の酸化物としての濃度であり， 他の 5 例の場合之は異なる。灰分と反応速度との関係は 灰分濃度が $500 \mathrm{ppm}$ 以上では大きくバラッキ，雨者の間 に明確な関連性を見出すととは困難である。同様に $\mathrm{Ca}$, $\mathrm{Ti}, \mathrm{V}, \mathrm{Ni}$ の場合もこれら濃度と反応速度との間に有意 の関連性を認めるととはできない。一方， Fe 濃度と水 蒸気反応速度との間には，一見して関連性のあるととが 伺える。最小自乗法によって両者の関係を直線表示した
ところ, その相関係数は 0.85 と求められた。しかし二酸 化炭素の場合は水蒸気より相関性は悪く, 係数は 0.69 で あった。Fig. 5 に Fe 亿 Ti，V，Ni を加えた合計濃度と $1000^{\circ} \mathrm{C}$ の反応速度の関係を示す。乙の場合の反応速度 之濃度との関係は $\mathrm{Fe}$ 単独の場合よりさらに良い相関性 を示す様になり，直線で表わした場合の相関係数は水蒸 気反応の場合が 0.92 , 二酸化炭素反応では 0.76 となった。 Fig. 5 の中の直線は反応速度を $\left(\mathrm{mg} / \mathrm{cm}^{2} \cdot \mathrm{hr}\right)$, 不純物濃 度を $\mathrm{ppm}$ で表わすと次の様になる。 


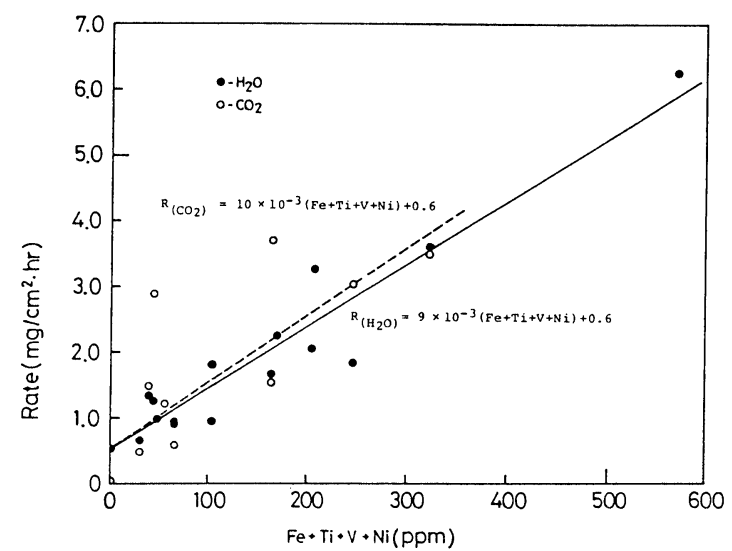

Fig. 5 Relation between the reaction rates with gases of $0.65 \%$ in helium at $1000^{\circ} \mathrm{C}$ and the total concentrations of $(\mathrm{Fe}+\mathrm{Ti}+\mathrm{V}+\mathrm{Ni})$ in the specimens

$$
\begin{aligned}
& R_{\mathrm{H}_{2} \mathrm{O}}=9 \times 10^{-3}(\mathrm{Fe}+\mathrm{Ti}+\mathrm{V}+\mathrm{Ni})+0.6 \\
& R_{\mathrm{CO}_{2}}=10 \times 10^{-3}(\mathrm{Fe}+\mathrm{Ti}+\mathrm{V}+\mathrm{Ni})+0.6
\end{aligned}
$$

反応の活性化エネルギーと $(\mathrm{Fe}+\mathrm{Ti}+\mathrm{V}+\mathrm{Ni})$ 濃度の 関係を Fig.6 亿示す。雨反応とも活性化エネルギーは濃 度の増加とともに減少する傾向を示すが，一見して反応 速度との場合より点のバラツキが大きいととがわかる。 直線で示した雨者の関係はそれぞれ次の様に表わせる。

$$
\begin{aligned}
& E_{\mathrm{H}_{2} \mathrm{O}}=-3 \times 10^{-2}(\mathrm{Fe}+\mathrm{Ti}+\mathrm{V}+\mathrm{Ni})+61 \\
& E_{\mathrm{CO}_{2}}=-11 \times 10^{-2}(\mathrm{Fe}+\mathrm{Ti}+\mathrm{V}+\mathrm{Ni})+66
\end{aligned}
$$

ここで $E_{\mathrm{H}_{2} \mathrm{O}}$ と $E_{\mathrm{CO}_{2}}$ は $\mathrm{kcal} / \mathrm{mol}$ で表わした水蒸気と二 酸化炭素による反応の活性化エネルギーである。

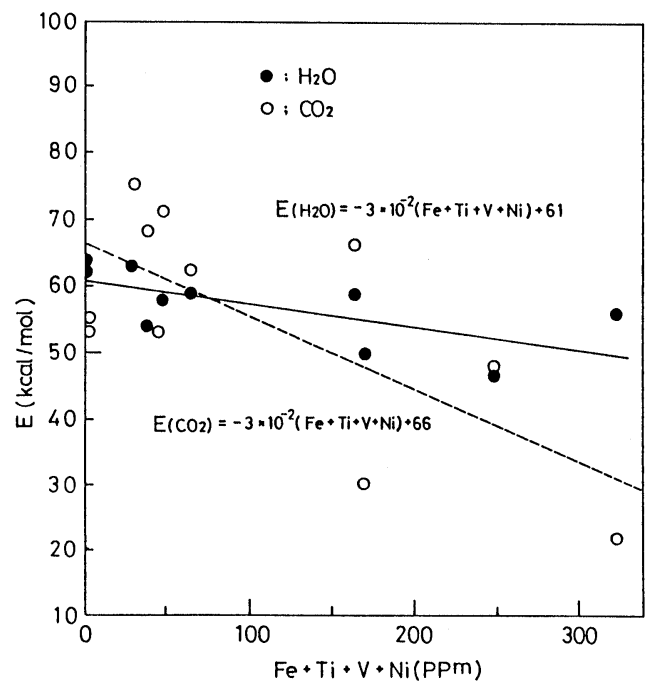

Fig. 6 Relation between the activation energies for the reactions and the total concentrations of $(\mathrm{Fe}+\mathrm{Ti}+\mathrm{V}+\mathrm{Ni})$ in the specimens

\section{3 反応速度と黒鉛化度, 結晶子径及び格子ひ ずみとの関連性}

$\mathrm{X}$ 線回折法で求めた試料の黒鉛化度 $g^{2}$, 結晶子径 $L_{\mathrm{c}}$, 格子ひずみ $\sigma_{\mathrm{c}}$ と反応速度との関係を Fig.7，8，9 亿示す。 黒鉛化度 $g^{2}$ の場合, Fig.7 に見られる様に反応速度は $g^{2}$ が 80 前後の所で上下に分散しており，雨者の間に一定 の関係は見られない。眓の中の 2 点のプロットを直線で 結んだものは同一素材で, $g^{2}$ は同じであるが試験片の

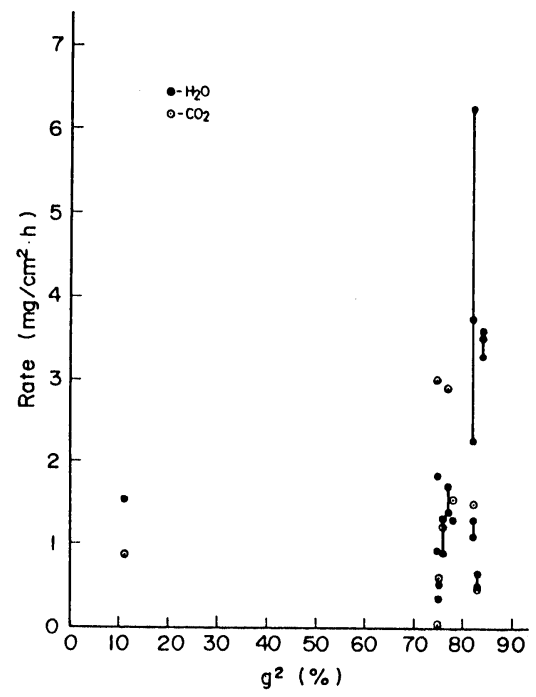

Fig. 7 Relation between the reaction rates with gases of $0.65 \%$ in helium at $1000^{\circ} \mathrm{C}$ and the degree of graphitization of crystallite in the specimens

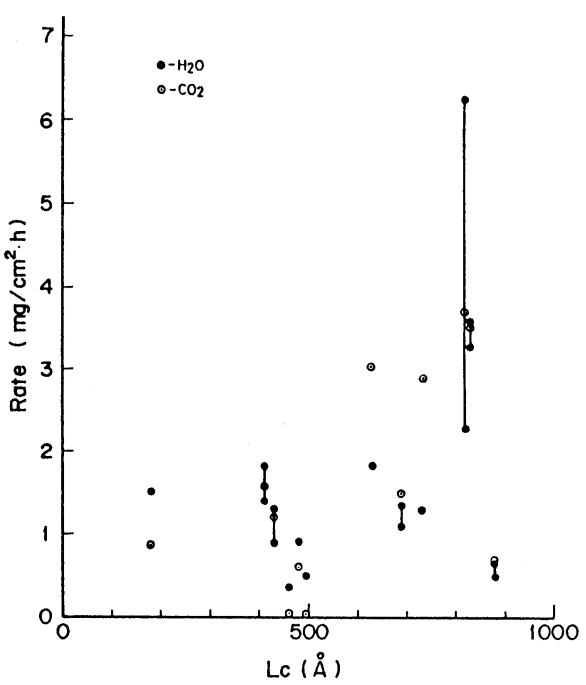

Fig. 8 Relation between the reaction rates with gases of $0.65 \%$ in helium at $1000^{\circ} \mathrm{C}$ and the height of crystallite in the specimens 


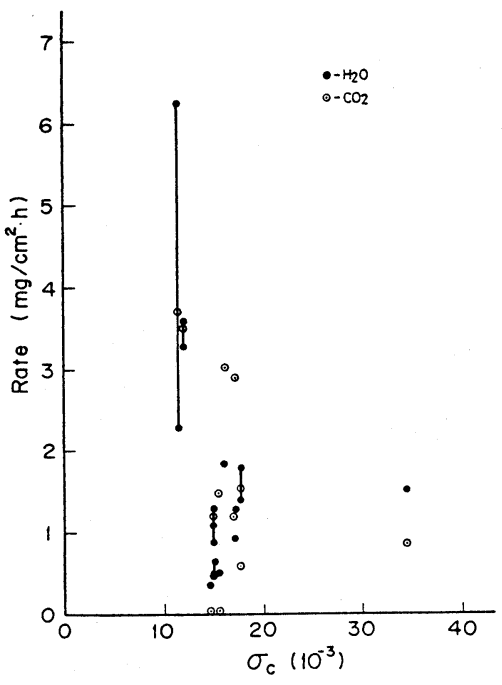

Fig. 9 Relation between the reaction rates with gases of $0.65 \%$ in helium at $1000^{\circ} \mathrm{C}$ and the $\mathrm{c}$-axis lattice strain of crystallite in the specimens

採取場所によって反応速度が異なった材料である。反応 速度は同一素材の場合，例外なく中心部分の方が外縁部 分より大きかった。な打 Fig. 8 と 9 の場合む 2 点を直線 で結んだものは同一素材で $L_{\mathrm{c}} や \sigma_{\mathrm{c}}$ は同じであるが, 反 応速度が異なった材料である。結晶子径 $L_{\mathrm{c}}$ の場合も反 応速度と $L_{\mathrm{c}}$ 值の間に一定の関係を見出すととは難しい。 格子ひずみの場合屯黒鉛化度の場合とほとんど同じ傾向 であり，ほぼ同じ $\sigma_{\mathrm{c}}$ の所で反応速度だけが変化している。

\section{4 反応のIso-Kinetic temperature}

反応速度 $R$ をアレニウスの式で表わした場合，雨反応

$$
R=A \cdot \exp \left(-\frac{E}{R^{\prime} T}\right)
$$

について $\ln A$ と $E$ の関係を Fig. 10 と 11 に示す。両反応

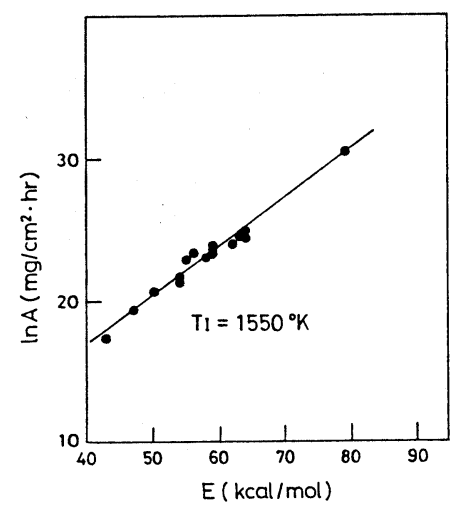

Fig. 10 Compensation effect for the reaction with water vapor

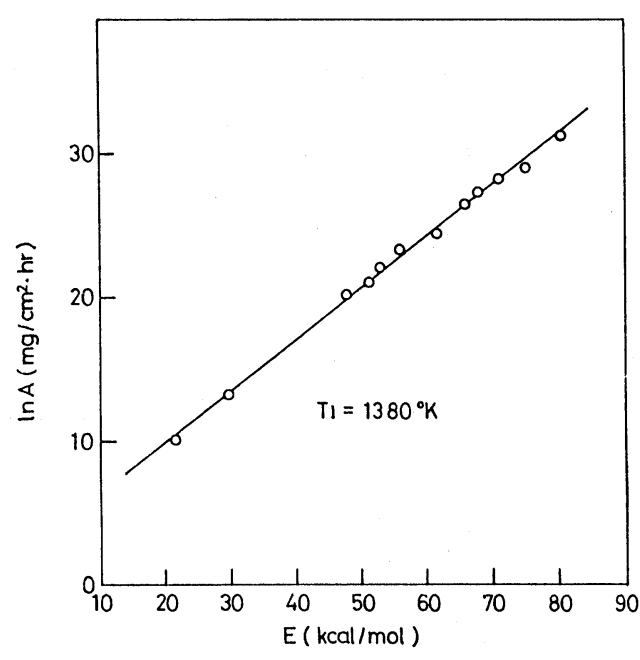

Fig. 11 Compensation effect for the reaction with carbon dioxide

とも各材料の測定点はきれいな直線上に並び，水蒸気反 応では

$$
\ln A=0.34 E+3.5
$$

二酸化炭素反応では

$$
\ln A=0.36 E+2.6
$$

と表わすととができた。今 (10)式や(11) 式の様に

$$
\ln A=m E+\ln K
$$

の様な一般的関係が成立する時，(9) 式は次の様传き 換えることができる。こてで $m$ は定数， $K$ は $E=0$ の時 のA值である。

$$
R=K \cdot \exp \left(m-\frac{1}{R^{\prime} T}\right) E
$$

(13) 式は（）内が零の時，すなわち温度 $T$ が $1 / m R^{\prime}$ に等しくなる時, 同種の反応の速度は $E$ の值に係わらず すべて $K$ という一定值になるととを示している5)。今と の温度, Iso-Kinetic temperature $T_{\mathrm{I}}$ を両反応につい て計算してみると水蒸気反応では $1550 \mathrm{~K}$, 二酸化炭素 反応では水蒸気反応より $170 \mathrm{~K}$ 低い $1380 \mathrm{~K}$ と求めるこ とができた。

\section{4. 考察}

\section{1 水蒸気による反応速度と二酸化炭素による 反応速度の相関性}

水蒸気による反応速度と二酸化炭素による反応速度の 相対的な比率については，乙れまでWalker 等による報 告と帛, Bonnetain 等によって求められた值がある7)。 前者は $800^{\circ} \mathrm{C}, 0.1 \mathrm{~atm}$ の反応ガス圧下で $R_{\mathrm{H}_{2} \mathrm{O}} / R_{\mathrm{CO}_{2}}$ が 3 , 後者の場合は $1000^{\circ} \mathrm{C}, 1 \mathrm{~atm}$ で 5 といずれの場合も水蒸 気の方が二酸化炭素より高い反応性を示したととが報告 
されている。当実験の 17 種類に及ぶ炭素・黒鉛材料か ら得られた $R_{\mathrm{H}_{2} \mathrm{O}} / R_{\mathrm{CO}_{2}}$ は $860^{\circ} \mathrm{C}$ で $0.9,1000^{\circ} \mathrm{C}$ で 1.1 で あった。文献值之実験值の $R_{\mathrm{H}_{2} \mathrm{O}} / R_{\mathrm{CO}_{2}}$ の相違は, 実験 值が 17 種類の炭素・黒鉛材料の平均的な值であるのに 対し, 文献值は特定の材料から求められた結果に依るも のであ万う。Fig.2や 3 の中にあ文献值に近い $R_{\mathrm{H}_{2} \mathrm{O}} / R_{\mathrm{CO}_{2}}$ をもつ材料はいくつかある。 $R_{\mathrm{H}_{2} \mathrm{O}} / R_{\mathrm{CO}_{2}}$ の実験值は炭素 や黒鉛表面の反応活性点が雨ガスで共通したものである ととを示唆している。

実験結果から $1000^{\circ} \mathrm{C}$ 内外の高温ガス炉の炉心温度環 境では, 黒鉛材料の水蒸気に上る反応速度と二酸化炭素 による反応速度をほぼ同等に見積ることができるという ととが明らかになった。したがってての実験の $0.65 \%$ と いうガス濃度で得られた結果が，実際の濃度条件である 微少ガス濃度でも成立するとすれば，高温ガス炉内の黒 鉛構造物の腐食は，基本的には冷却材中の水蒸気濃度が 二酸化炭素濃度分だけ增加したとして評価できる。

\section{2 反応速度と含有不純物及び反応の活性化エ} ネルギーと含有不純物との関連性

この研究の目的の一つは銘柄で異なる炭素や黒鉛材料 のガス化反応データを普遍化できる因子を見出すととに ある。そこでまず反応速度に大きく影響することが知ら れている含有不純物との関連性を調べた。両反応とも含 有不純物のなかでは Fe のみが反応速度と高い関連性を 示し，他の元素では有意の関連性を見出すととができな かった。Thrower等は最近水蒸気との反応では $\mathrm{Ca}>\mathrm{Fe}$ $>\mathrm{V}$ の順で触媒活性があり, 二酸化炭素との反応では $\mathrm{V}$ $>\mathrm{Ca}>\mathrm{Fe}$ の順であるととを報告している ${ }^{8)}$ 。乙てで得 られた結果は雨反応とも Thrower 等の報告とは異なっ ているが，乙の実験でVの触媒効果が認められなかった のはVの濃度が $\mathrm{Fe}$ や $\mathrm{Ca}$ の $10^{-1}$ の濃度以下であったた めと考元ら机る。しかし水蒸気に上る反応で $\mathrm{Ca}$ の触媒 効果に相違が生じた原因はわからない。Fe $\mathrm{Ni}$ を加えた濃度因子と反応速度の関係が $\mathrm{Fe}$ 単独の場合 より高い関連性をもつ様になるという事実は，てれら不 純物元素が $\mathrm{Fe}$ と同等の触媒作用を発揮したととを示す あのと考えることができる。これらの元素が単独では関 連性を示さなかったのは Vの効果のととろで述べた様に, その濃度の問題であろう。乙れらの不純物は $\mathrm{Fe}$ の $10^{-1}$ 以下の濃度であるため, 反応速度はほとんど $\mathrm{Fe}$ 濃度に よって左右されたものと考えられる。( $\mathrm{Fe}+\mathrm{Ti}+\mathrm{V}+\mathrm{Ni})$ 濃度と反応速度との相関性は, 得られた反応速度を個々 の材料の比表面積で補正するととによって，さらに向上 させ得るものと考えられる。

黒鉛結晶とガスとの反応は雨相の界面で起る反応であ る。不純物元素が結晶表面に存在する面積濃度は体積濃
度の $2 / 3$ 乗になるから, 黒鉛結晶表面のみの不純物元素が 反応に関与するならば, 反応速度と体積濃度との関係は Fig.5の様に直線関係にはならない。以上の理由から実 験結果は黒鉛結晶表面加ある深さまでに存在する特定 の不純物元素が反応に関与するととを示すすのと考えら れる。炭素のガス化反応に抢ける不純物元素の触媒作用 機構として二つの説がある ${ }^{9,10)}$ 。その一つは不純物元素 が反応ガスと中間生成物を形成し，その中間生成物之炭 素の間で反応が進み，乙の過程がサイクリックに行なわれ るというあのである。他の一つは不純物元素が炭素結晶

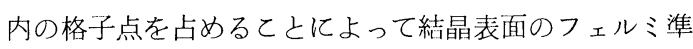
位が変化し， C-C 結合を弱くして反応を増進させると いうものである。との二つの作用機構を考えた場合，前 者では結晶表面にある不純物元素のみが反応に関与する のに対し，後者では表面からある深さまでの不純物元素 が反応に係わることになる。したがってての実験で得ら れた結果は不純物元素の触媒機構が前者より後者である 可能性を示している。

反応の活性化エネルギーと $(\mathrm{Fe}+\mathrm{Ti}+\mathrm{V}+\mathrm{Ni})$ 濃度之 の関連性は, 反応速度と濃度との相関性より悪くなった。 反応速度の場合 $1000^{\circ} \mathrm{C}$ では水蒸気反応で 0.92 , 二酸化 炭素反応で 0.76 であったが, 活性化エネルギーとの相関 係数は前者が 0.65 , 後者が 0.69 であった。乙の様に反応 の活性化エネルギーとの場合, 相関性が悪くなるのは活 性化エネルギーが反応速度の温度変化から求められる二 次的な特性であるためであろう。

\section{3 反応速度と黒鉛化度, 結晶子径及び格子ひ ずみとの関連性}

一般に黒鉛化度が低く結晶が大きく発達していない炭 素は高いガス化速度を示すということがいわれる。しか しこの実験では黒鉛化度, 結晶子径, 格子ひずみのいず れについても関連性を見出すととができなかった。固気 相反応では固体の表面あるいは表面近傍部分の原子のみ が反応に関与するから，その反応性はその部分の状態に 大きく依存するであろう。炭素に限らず固体では表面部 分の結晶状態は幾何学的に乱れた状態になっており，そ の乱れ方は結晶内部の結晶性の良し悪しや, 結晶子の寸 法によって大きく変るあのではないであろう。したがっ ててれら因子の影響は大きくないてとが予想できる。こ れら因子の影響は不純物の触媒効果にかくれてしまう程 度であったため相関性を見出すととができなかったもの と考えられる。

\section{4 反応のIso-Kinetic temperature}

炭素・黒鉛のガス化反応では一般に触媒反応で観察さ れるCompensation effectが現われる ${ }^{9)}$ 。このととは炭 素・黒鉛材料のガス化反応が触媒によって支配される反 
応の一つの証しであある。多孔質材料である炭素材料や 黒鉛材料とガスとの反応では, 低温から高温に向って化 学反応律速, 細孔内拡散律速, 境膜内拡散律速の三律速 機構のあることが知られている ${ }^{6)}$ 。化学反応律速では材 料の屯つ化学反応性がそのまま反応速度に反映される。 一方, 高温で現われる境膜内拡散律速では反応がガスの 拡散速度によって支配されるため, 反応速度は材料のも つ化学反応性之無関係になり，材料による相違はなくな る。しかし炭素・黒鉛材料の反応でCompensation effect が見られるというととは，化学反応律速を高温まで維持 したとしても，各材料の反応速度はある温度で等しくな るということを示している。ての実験で求めたてのIso 一 Kinetic temperature，すなわちすべての同種の反応 速度が等しくなる温度 $T_{\mathrm{I}}$ は水蒸気反応では $1550 \mathrm{~K}$, 二

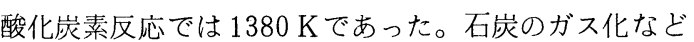
では効率良くガス化を進めるために石炭を細粉化し，触 媒を使用して化学反応律速を高温まで維持する方が得策 であるが，Iso-Kinetic temperatureになると触媒の効 果は消滅するあのと考えられる。

原研で開発をすすめている高温ガス実験炉の場合，通 常時における黒鉛構造物の最高温度は $1520 \mathrm{~K}$ である。 炭素や黒鉛の化学反応性が反応速度に影響を与えない温 度，すなわち境膜内拡散律速によって反応が進行する様 になる温度は, 原子炉級黒鉛と水蒸気, 或いは二酸化炭 素之の反応では 1500 1600 Kである ${ }^{11)}$ 。したがって高 温ガス実験炉における黒鉛構造物の腐食では常に不純物 元素の触媒作用を考慮しておくことが必要である。

\section{5. 謝辞}

本論文をまとめるに当り，御助言と御激励を頂きまし た岩本燃料工学部長に感謝致します。

\section{文献}

1) 今井 久, 日本原子力学会誌 22,769 (1980)

2) J. Méring and J. Maire, Les Carbons 1, 129 (1965)

3) P. A. Thrower and D. C. Nagle, Carbon 11, 663 (1973)

4) 日本原子力研究所, 未公開データ

5) G. C. Bond, Catalysis by metals, Academic Press, London and New York (1962) p. 139

6) P. L. Walker, Jr., Frank Rusinko, Jr., and L. G. Austin, Advances in Catalysis, Academic Press, New York and London, Vol. 11 (1959) p. 133

7) L. Bonnetain and G. Hoynant, Les Carbons 2, 277 (1965)

8) P. A. Thrower, G. K. Mathew, and N. J. McGinnis, Carbon 20, 465 (1982)

9) P. L. Walker, Jr., M. Schelef, and R. A. Anderson, Chemistry and Physics of Carbon, Marcel Dekker, Inc., New York, Vol. 4 (1968) p. 287

10） F. F. ボリケンシティン, 半導体触媒作用の電子論, 佐藤市三郎訳，横川書房 (1970), p. 135

11) M. R. Everett, D. V. Kinsey, and E. Romberg, Chemistry and Physics of Carbon, Marcel Dekker, Inc., New York, Vol. 3 (1968) p. 289 